\title{
Do mangroves rather than rivers provide nutrients to coastal environments south of the Amazon River? Evidence from long-term flux measurements
}

\author{
Thorsten Dittmar*, Rubén José Lara
}

Zentrum für Marine Tropenökologie, Fahrenheitstr. 6, 28359 Bremen, Germany

\begin{abstract}
Mangroves play an important role in the biogeochemical cycles of coastal and marine ecosystems in the tropics. However, few studies have been carried out to clarify the extent to which mangroves represent a source of nutrients and organic matter for adjacent coastal waters or function, alternatively, as a sink. Here we present results of a long-term nutrient-flux study in one of the world's largest mangrove areas in North Brazil. These are up to now the only published nutrient flux data for Brazilian mangroves, and constitute one of the most comprehensive data sets in this field. Throughout 36 tidal cycles in the course of 1 yr, fluxes of organic carbon (DOC, POC), nitrogen (DON, PON) and dissolved inorganic nutrients ( $N, \mathrm{Si}, \mathrm{P}$ compounds) were determined in a tidal creek connecting a clearly defined area of mangroves $\left(2.2 \mathrm{~km}^{2}\right)$ with the Caeté Estuary. Additionally, a qualitative whole-estuary approach was applied $\left(190 \mathrm{~km}^{2}\right.$ of mangroves). Both methods revealed an outwelling of dissolved organic matter and nutrients from the mangroves, exceeding considerably that of mangroves in other regions of the world. This net export was (annual average, $\mathrm{mmol}^{2} \mathrm{~m}^{2} \mathrm{man}-$ grove $]^{-1} \mathrm{~d}^{-1}$ ) DOC $\approx 10, \mathrm{DON} \approx 0.7$, ammonium $\approx 0.2$, silicate $\approx 6$ and phosphate $\approx 0.02$. Nitrate fluxes were comparatively low. Silicate and phosphate were exported mainly during the dry season and DON during the rainy season. DOC showed no seasonal trend. Especially ammonium fluxes presented strong asymmetries between day and night. Although only $\sim 6 \%$ of the fluvial catchment area is covered by mangroves, their nutrient export exceeded that of the hinterland. The annual export from mangroves on a regional scale $\left(6700 \mathrm{~km}^{2}\right.$ from $0^{\circ} \mathrm{S}, 50^{\circ} \mathrm{W}$ to $\left.3^{\circ} \mathrm{S}, 42^{\circ} \mathrm{W}\right)$ was estimated $\left(\mathrm{mol} \mathrm{yr}^{-1}\right)$ as DOC $\approx 30 \times 10^{9}, \mathrm{DON} \approx 2 \times 10^{9}$, ammonium $\approx 0.4 \times 10^{9}$, silicate $\approx 15 \times 10^{9}$ and phosphate $\approx 0.04 \times 10^{9}$. Compared with the Amazon River discharge these fluxes are low (1 to $3 \%$ of the Amazon fluxes). The nutrient cycles of coastal marine environments are probably mangrove-dominated southeast of the Amazon Estuary, contrary to the river-dominated cycles to the northwest.
\end{abstract}

KEY WORDS: Outwelling $\cdot$ Nutrients $\cdot$ Organic matter $\cdot$ Mangrove $\cdot$ Brazil Resale or republication not permitted without written consent of the publisher

\section{INTRODUCTION}

Mangrove forests belong to the major ecosystems of the biosphere, and about 60 to $75 \%$ of tropical coasts are fringed by this highly productive ecosystem (MacGill 1958, Clough 1998). Plant litter, mainly leaves, represents about one-third of primary production in mangrove forests, and up to half this quantity

\footnotetext{
*Present address: Alfred-Wegener-Institut für Polar- und Meeresforschung, Am Handelshafen 12, 27570 Bremerhaven, Germany.E-mail: tdittmar@awi-bremerhaven.de
}

can be exported via creeks to adjacent waters (Robertson et al. 1992). The export of these large amounts of organic material has a recognisable effect on the food webs in coastal waters (e.g. Odum \& Heald 1975, Alongi et al. 1989, Alongi 1990). Despite the important role mangroves play in the biogeochemical cycles of coastal and even off-shore environments, very few quantitative studies have been carried out in the past to clarify the extent to which mangroves represent a significant source of inorganic and organic nutrients for adjacent coastal waters or function, alternatively, as a sink. 
The information available is confined to few regions in the world: Hinchinbrook Island (Australia) is the only mangrove area for which a quantitative long-term export balance for inorganic and organic nutrients has been obtained (Boto \& Bunt 1981, Boto \& Wellington 1988, Alongi 1996, Alongi et al. 1998, Ayukai et al. 1998). In Terminos Lagoon (Mexico), the information is limited to nitrogen species (Rivera Monroy et al. 1995). Wattayakorn et al. (1990) studied the export of inorganic nutrients in Klong Ngao (Thailand), and Twilley (1985) determined the export of dissolved and particulate organic carbon in Rookery Bay (Florida, USA). A general consensus on nutrient outwelling from mangroves has not yet been reached. Many inconsistencies in the published data may have resulted from methodological differences and difficulties in accurately determining material fluxes in mangrove areas, mainly due to their large and apparently random tidal-dependent oscillations (Boto \& Wellington 1988). Furthermore, variations between the studied mangroves, such as tidal range, topography, sediment chemistry or community structure are put forward as possible reasons for inconsistencies among export balances (Ayukai et al. 1998).

In this study, we present the results of detailed longterm flux measurements of dissolved inorganic nutrients and organic matter in one of the world's largest mangrove areas in North Brazil. The fluxes between a well-defined mangrove catchment area and adjacent coastal marine environments were quantified. Additionally, a qualitative whole-estuary approach was applied to evaluate the quantitative data on an extended spatial scale and to compare mangrove outwelling with riverine fluxes. Besides the work in Hinchinbrook
Island, this is the most comprehensive study in this field, and constitutes the only nutrient flux data for Brazilian mangroves publised so far.

\section{MATERIALS AND METHODS}

Study area. The research area, the estuary of the Caeté River, is located approximately $150 \mathrm{~km}$ to the southeast of the Amazon Estuary near Bragança (Fig. 1). The mangroves in the area comprise well-developed forests, with tree heights reaching about $20 \mathrm{~m}$. The dominant species are Rhizophora mangle, Avicennia germinans and Laguncularia racemosa. Annual average temperature and rainfall are about $25.5^{\circ} \mathrm{C}$ and $2550 \mathrm{~mm}$, respectively, with $75 \%$ of the precipitation occurring in the rainy season between January and May (INMET 1992).

The catchment area of the Caeté River comprises about $3000 \mathrm{~km}^{2}$, of which $6 \%\left(190 \mathrm{~km}^{2}\right)$ is covered by mangroves. Upstream, secondary forest, agriculture and cattle farming dominate the landscape (Schwendenmann 1998). The Caeté Estuary is characterised by macro-tides with tidal amplitudes of about $4 \mathrm{~m}$. A major part of the mangrove is inundated only fortnightly during spring tides. The estuary is shallow even at the mouth, with maximum water depths at high tide of about $10 \mathrm{~m}$, and it is well-mixed (Dittmar 1999).

The tidal creek investigated ('Furo do Meio': Fig. 1) is about $4 \mathrm{~km}$ long and is situated near the outer part of the estuary. The sampling site is situated in the central part of the mangrove forest, where the creek has a width of approx. $35 \mathrm{~m}$ and a maximum depth of approx. $5 \mathrm{~m}$ at high tide. At low tide, the creek water

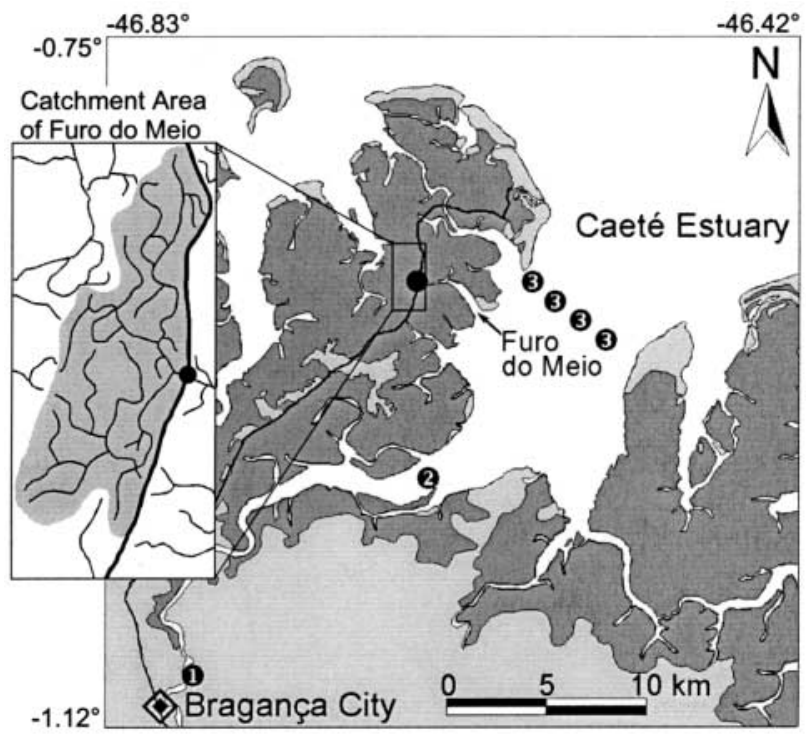

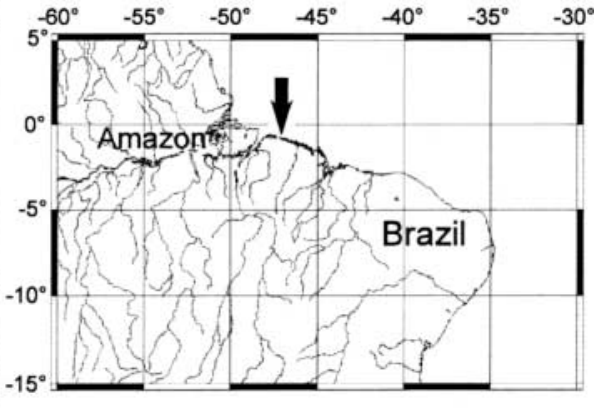

Landscape:

Mangrove

Other

- Sampling Stations

$\sim$ Road
Fig. 1. Location of study site and mangrove area to west of the road embankment, which is drained exclusively by Furo do Meio $\left(2.2 \mathrm{~km}^{2}\right)$ 
composition is dominated by porewater, which flows from the mangrove sediment into the creek, where it causes high concentrations of nutrients and organic matter (Lara \& Dittmar 1999). Within the forest, an abundant benthic macrofauna (mainly landcrabs) leads to significant sediment bioturbation and to the retention of most litter in the forest (Dittmar 1999).

The embankment of a road (Fig. 1) impedes water flow between the western and the eastern part of the peninsula except through tidal creeks passing below bridges. As evident from satellite images and field work, to the west of the road, the Furo do Meio tidal creek and its tributaries are not connected with other tidal creeks and do not reach the other side of the peninsula. There is a well-defined area of mangroves to the west of the road which is drained exclusively by Furo do Meio (2.2 $\mathrm{km}^{2}$; Fig. 1). Material fluxes to this area can therefore exactly be determined by monitoring the fluxes below the Furo do Meio bridge. The deep tidal channels carving the flat landscape and the high near-surface groundwater table in the forest preclude sub-surface hydrological continuities over longer distances and preclude any considerable groundwater inflow from neighbouring areas. This semi-enclosed system at Furo do Meio therefore facilitates the application of a simple balance model for a reliable estimate of net material fluxes between mangrove and estuary.

Sampling and chemical analyses. At the bridge across Furo do Meio, surface samples were taken from the middle of the creek hourly for $24 \mathrm{~h}$ every $3 \mathrm{wk}$ between July 1996 and August 1997 (36 tidal cycles). Within the estuary, samples were taken hourly at 3 fixed stations mid-stream (Fig. 1) at 2 depths (surface and $0.5 \mathrm{~m}$ above ground) every $9 \mathrm{wk}$ ( 7 campaigns). In the mouth of the estuary (Stn 3), 4 sub-stations were sampled on a transect perpendicular to the flow direction. All campaigns were carried out at neap and spring tides alternately. Stns 1 and 3 were considered to be the limits of the estuary. In the following, the term 'river water' is used for freshwater (Stn 1, low tide) and 'marine water' for water of maximum salinity (Stn 3, high tide), flowing into the estuary.

Details of sample preparation and analyses are described elsewhere (Dittmar 1999, Lara \& Dittmar 1999). Briefly: dissolved oxygen, $\mathrm{pH}$, and salinity were measured in situ with portable instruments, and vertical profiles of these parameters were obtained with a mini CTD-probe (Multipar). Samples were filtered (Whatman GF/C), fixed, and frozen immediately after sampling. Dissolved inorganic nutrients were measured by standard autoanalyser methods using a Skalar-SAN-plus system according to Hansen \& Grasshoff (1983). Dissolved inorganic nitrogen (DIN) was calculated as DIN $=\mathrm{NO}_{3}{ }^{-}+\mathrm{NO}_{2}{ }^{-}+\mathrm{NH}_{4}{ }^{+}$. Dissolved organic nitrogen (DON) was determined by wet oxidation using persulfate as oxidising reagent (Koroleff 1977, 1983). Dissolved organic carbon (DOC) was measured by high-temperature catalytic oxidation with a Rosemount-Dohrman DOC-190 system (Statham \& Williams 1983, Skoog et al. 1997). GF/C filters were analysed for particulate organic carbon (POC) and nitrogen (PON) by high-temperature flash combustion with a Fisons NA 2100 element analyser. For the determination of total suspended solids (TSS), the residues on the GF/C filters were gravimetrically quantified. The relative standard deviations for each method and each run were less than $3.5 \%(p=0.05)$.

Material flux estimates. Material concentrations measured in the Caeté Estuary were plotted against salinity for each sampling campaign. Conservative mixing of freshwater with marine water leads to a linear relationship between salinity and solute concentration. Non-conservative behaviour is reflected in deviations from linearity. This qualitative approach was used on a whole-estuary scale to discriminate between riverine, mangrove and marine inputs. The rapid particle resuspension and deposition in estuarine systems preclude the application of this approach to suspended solids (TSS, POC, PON).

For the quantitative determination of material fluxes between the mangrove area and the estuary, an 'Eulerian' approach was applied at Furo do Meio. Material flux increments below the bridge of the tidal creek were calculated as the product of water discharge and material concentration and added over a tidal cycle to obtain net fluxes. This method has been applied in most flux studies (Boto \& Bunt 1981, Twilley 1985, Boto \& Wellington 1988, Wattayakorn et al. 1990, Alongi 1996, Alongi et al. 1998, Ayukai et al. 1998). It has also often been criticised, since material exchange in mangroves does generally not take place in distinct channels and potentially large errors are introduced by the inaccuracy of flow and concentration measurements (e.g. Kjerfve et al. 1981). Rivera Monroe et al. (1995) used an artificial $12 \mathrm{~m}$ flume to determine material exchange between a small area of mangroves and a tidal creek. Wattayakorn et al. (1990) and Ayukai et al. (1998) calculated the material flux in mangrove creeks from the tidal diffusion equation assuming a conservative behaviour of the material of interest. At Furo do Meio, the semi-enclosed catchment area and the welldefined pathways of material exchange are particular conditions for the application of the 'Eulerian' approach. It provides information on a considerable area of mangroves $\left(2.2 \mathrm{~km}^{2}\right)$ and does not require further simplifications. The reliability of the method was checked by water balances and a comparison with the whole-estuary approach.

Details of the 'Eulerian' approach are described in the following. The water flow at Furo do Meio takes 
place in a well-defined cross-section below a bridge. The cross-sectional area could be described as a quadratic function of water level $(\mathrm{r}=1.00, \mathrm{n}=22)$. The latter was measured with a gauge every 15 min and the corresponding cross-sectional area was calculated. Current velocity was registered once a minute with a Sensordata 6000 current meter in the middle of the creek. The deployment depth of the current meter was adjusted every $15 \mathrm{~min}$ to a distance above ground of 0.4 times the water level (Gils 1958, Kreps 1975). To reduce noise, the data from the automatic current meter were averaged over 5 min periods prior to further analysis. The water level presented very regular tidal oscillations (Dittmar 1999). Thus, a cubic spline interpolation could be used to interpolate between the water levels measured every $15 \mathrm{~min}$. The cross-sectional area was determined every $5 \mathrm{~min}$ on this basis. By multiplying the cross-sectional areas with the corresponding current velocities water fluxes were obtained every $5 \mathrm{~min}$.

Nutrient and organic matter (OM) concentrations exhibited regular and smooth tidal oscillation, in contrast to current velocity. A temporal resolution of $1 \mathrm{~h}$ reflected tidal oscillations well (Dittmar 1999, Lara \& Dittmar 1999). Thus, a cubic spline interpolation could be used to derive concentration data for every $5 \mathrm{~min}$. Material flux increments were calculated as the product of water flux and material concentration and added over a lunar day ( 2 tidal cycles, approx. $24 \mathrm{~h} 40 \mathrm{~min}$ ) to obtain net fluxes. The net fluxes throughout a lunar day were then normalised to $24 \mathrm{~h}$ and to the catchment area of Furo do Meio $\left(2.16 \mathrm{~km}^{2}\right)$ :

$$
\begin{gathered}
F=\sum_{i=1}^{4}\left(x_{i} \cdot \sum_{t=t_{\mathrm{b}}}^{t_{\text {ie }}} c_{t} \cdot Q_{t}\right) \cdot \frac{24 \mathrm{~h}}{24 \mathrm{~h} 40 \mathrm{~min}} \cdot \frac{1}{2.16 \cdot 10^{6} \mathrm{~m}^{2}} \\
x_{i}=\frac{\frac{1}{4} \cdot \sum_{i=1}^{4}\left(\sum_{t=t_{\mathrm{b}}}^{t_{\text {ie }}} S_{t} \cdot Q_{t}\right)}{\sum_{t=t_{\mathrm{ib}}}^{t_{\text {ie }}} S_{t} \cdot Q_{t}}
\end{gathered}
$$

where $F=$ net material flux per day and mangrove area $\left(\mathrm{mmol} \mathrm{d}^{-1} \mathrm{~m}^{-2}\right), i=$ number of half-tidal cycle, $x_{i}=$ correction factor for half-tidal cycle $i, t_{i \mathrm{~b}}=$ beginning of half-tidal cycle $i, t_{i \mathrm{e}}=$ end of half-tidal cycle $i, c_{t}=$ material concentration at time $t_{\mathrm{k}}\left(\mathrm{mmol} \mathrm{m}^{-3}\right), S_{t}=$ salinity at time $t_{\mathrm{k}}, Q_{t}=$ water-flux at time $t_{\mathrm{k}}\left(\mathrm{m}^{3}\left[t_{\mathrm{k}+1}-t_{\mathrm{k}}\right]^{-1}\right)$.

In this region, the tides present considerable diel asymmetries (Dittmar 1999), so the net flux of water is not necessarily balanced throughout a complete tidal cycle of flood and ebb. The calculation of daily net material fluxes thus necessitated a correction of the water fluxes to avoid methodological artefacts. For this purpose, salinity was used as conservative parameter.
Differences in salt fluxes between half-tidal cycles were compensated using an individual correction factor for each half-cycle $\left(x_{i}\right)$. The water and material fluxes at each moment were then corrected using these factors for each half-cycle individually (Eqs. 1 \& 2):

$$
Q_{c t}=Q_{t} \cdot x_{i}
$$

where $Q_{c t}=$ corrected water discharge at time $t_{\mathrm{k}}\left(\mathrm{m}^{3}\right.$ $\left.\left[t_{\mathrm{k}+1}-t_{\mathrm{k}}\right]^{-1}\right)$.

The parameter $F^{*}$ (Eq. 3) was established in this study as a standardised measure for deviations of net fluxes from the balanced state. $F^{*}$ is the net material flux per day $(F)$ normalised to total material input per day. For example, if the outflow of any parameter during ebb is twice the inflow during flood, then the normalised net material flux is $F^{*}=-100 \%$. The net flow would be far from the balanced state $\left(F^{*}=0 \%\right)$, and the net export would be high.

$$
F^{*}=\frac{F^{\prime}}{\sum_{i=1}^{2}\left(x_{i} \cdot \sum_{t=t_{i \mathrm{~b}}}^{t_{i \mathrm{e}}} c_{t} \cdot Q_{t}\right)} \cdot 100 \%
$$

where $F^{*}=$ normalised net material flux ( $\%$ of flood), $F^{\prime}=$ net material flux per lunar day (mmol $[24 \mathrm{~h}$ $40 \mathrm{~min}^{-1}$ ), and $Q_{t}=$ water inflow at flood $i$ and time $t_{\mathrm{k}}$ $\left(\mathrm{m}^{3}\left[t_{\mathrm{k}+1}-t_{\mathrm{k}}\right]^{-1}\right)$.

\section{RESULTS}

\section{Whole-estuary approach}

A continuous source of DIN and silicate in the mangrove-fringed part of the estuarine catchment area caused concentrations in the estuary that were up to several times higher than in 'river water' or 'marine water' (Fig. 2). This was found throughout the whole year of sampling, independent of season and the amount of freshwater in the estuary. The high degree of the deviations from conservative mixing furthermore shows that this source contributed generally higher amounts of DIN and silicate to the estuary than did freshwater sources. The shape of the mixing curves changed in May 1997 and July/August 1997. This was due to the exceptionally wide range of salinity at Stns 2 and 3 during this period of the year and not to changing source characteristics, as DIN and silicate still behaved non-conservatively.

Phosphate, in contrast, exhibited no consistent but only random deviations from conservative mixing during the rainy season (Fig. 2b). In the dry season, however, phosphate deviated consistently from conservative mixing (Fig. 2a). An additional flux of phosphate to the estuary then exceeded its input by freshwater. This was evident mainly on 15 to 17 January 1997. 
(a) Dry Season
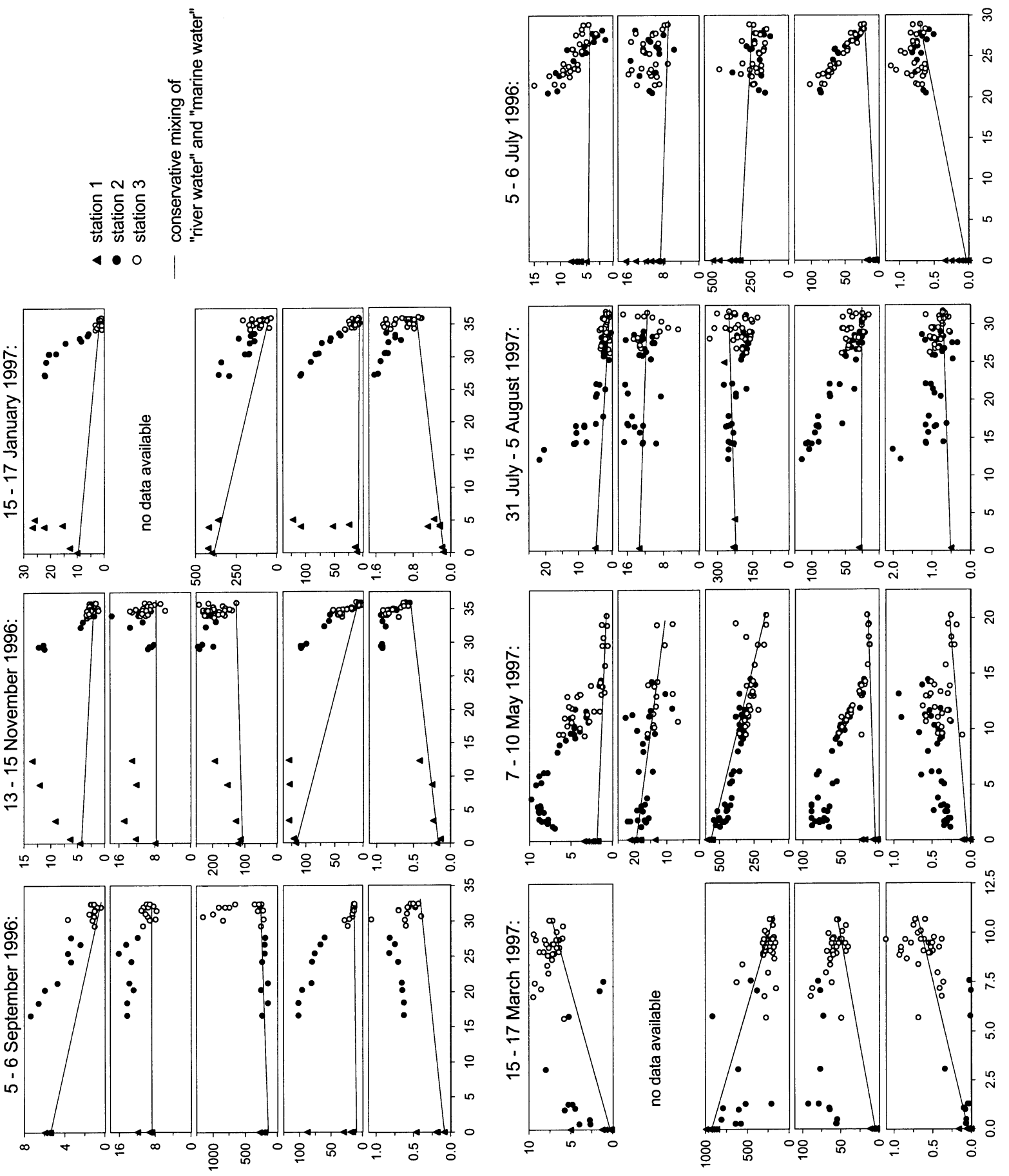

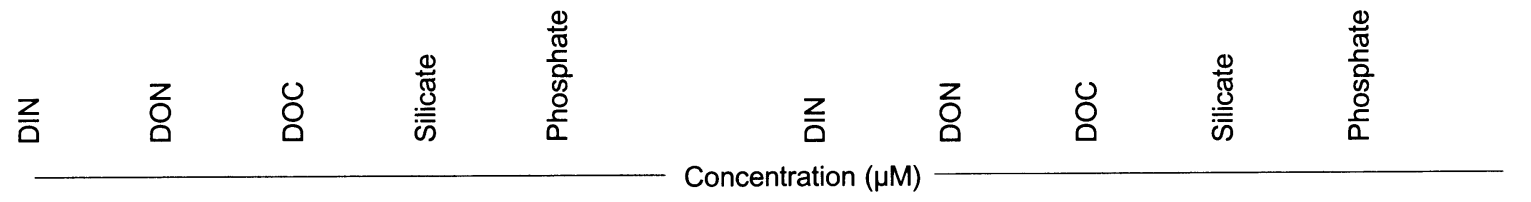

Fig. 2. Mixing diagrams (concentration vs salinity plots) for nutrients and DOM in the Caeté Estuary in dry season (1996/1997), and rainy season (1997 and end of rainy season 1996) 


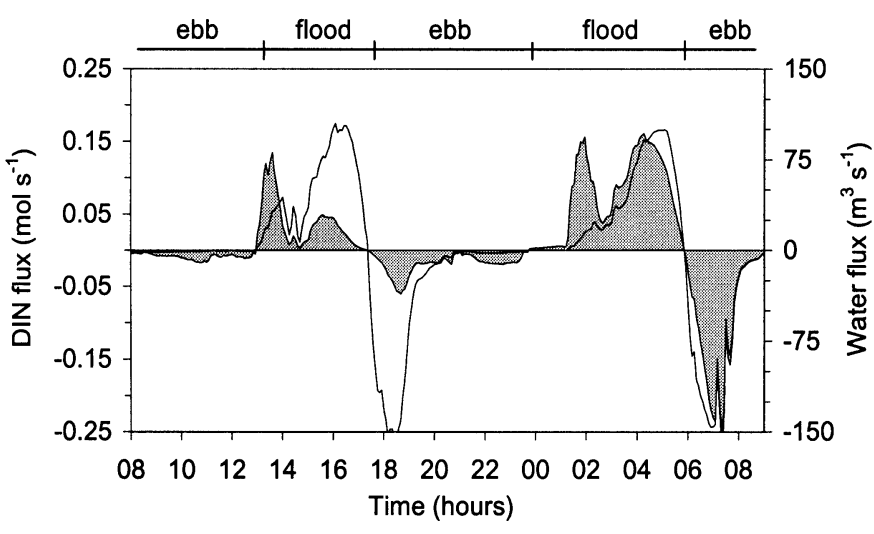

Fig. 3. $24 \mathrm{~h}$ time series of DIN fluxes (grey) and corrected water discharge $\left(Q_{c t}\right.$, line) on 25/26 September 1997 at Furo do Meio

In contrast to inorganic nutrients, DOC and DON showed apparently random variations throughout the whole year and only slight or no significant concentration increases relative to conservative mixing along the estuary. Strong variations in DOC concentration were observed mainly on 5 to 6 September 1996 at Stn 3. These variations were not related to salinity. They were caused by a strong concentration increase close to the coast, which was observed in almost all sampling campaigns.

\section{‘Eulerian' approach}

The example shown in Fig. 3 illustrates several features of water and nutrient fluxes between the catchment area of Furo do Meio and areas downstream, i.e. the Caeté Estuary, at high temporal resolution (5 min). Nutrient- and OM-rich water accumulated in the tidal creek at low tide, without being exported to the estuary. At the beginning of flood tide, this solute-rich water body returned to the mangrove as indicated by a pronounced peak in material import at this time. A second peak of material transport was associated with increasing water influx about $2 \mathrm{~h}$ before high tide. This double-peaked inflow was exhibited in the time series of DIN, silicate and phosphate, in particular. The outflow, however, was characterised by a single maximum and oscillations almost parallel to the water discharge. The flux during ebb was always directly associated with the preceding flood, independent of the time of day: the first ebb began just before sunset, but the DIN flux was still reduced to the same degree as during the flood at daytime. The second ebb began at sunrise, and the DIN fluxes were at the same level as the preceding flood at night.
On annual average, the net export of all dissolved inorganic and organic compounds from the creek's catchment area was statistically significant (Tables 1 \& 2). An exception was the flux of nitrate + nitrite, which was balanced on annual average, whereas outwelling of ammonium was evident. The majority of the total dissolved nitrogen, however, was exported as organic material: about 5 times more DON than DIN from the mangroves on annual average (Table 1).

Despite the clear evidence of general outwelling in the long-term, DIN net fluxes oscillated strongly throughout the year, without significant seasonal or tidal trends (Fig. 4). Maxima of import or export were present both at spring and neap tides. DON fluxes, however, showed a clear annual trend. During the dry season no significant deviations from the balanced state were found, whereas during the rainy season, there was a significant net export of DON from the mangroves. Maximum DON net fluxes always occurred simultaneously with PON maxima. PON covaried generally in a tight fit with TSS and POC (Fig. 5). TSS fluxes were generally low relative to the extraordinary TSS net export during strong rainfalls and pluvial erosion in the forest. On an annual basis, a significant DOC export from the mangrove was determined. Unlike DON, its fluxes showed no seasonal or tidal trends, and maximum POC export during some days in the rainy season had no effect on DOC export.

Silicate and phosphate showed clear seasonal trends. Throughout the year, silicate was mostly exported. On only 2 campaigns in May 1997 was silicate import to the mangrove detected. Silicate export was significantly higher during the dry season than during the rainy season (Table 1). Significant exports of phosphate occurred throughout the dry season. During the rainy season, however, its net fluxes oscillated more, and on average the phosphate exchange was almost balanced.

Table 1. Average daily net fluxes $\left(\mathrm{mmol} \mathrm{m} \mathrm{m}^{-2} \mathrm{~d}^{-1}\right)$ from the mangrove system at Furo do Meio to the estuary, with confidence intervals $(p<0.05)$. For clarity, only significantly different average values ( $p<0.05$, Student's $t$-test) are shown for the 2 seasons

\begin{tabular}{|lccc|}
\hline Nutrients & $\begin{array}{c}\text { Year } \\
(\mathrm{n}=17)\end{array}$ & $\begin{array}{c}\text { Dry season } \\
(\mathrm{n}=7)\end{array}$ & $\begin{array}{c}\text { Rainy season } \\
(\mathrm{n}=10)\end{array}$ \\
\hline $\mathrm{DIN}$ & $-0.16 \pm 0.15$ & & \\
$\mathrm{NH}_{4}{ }^{+}$ & $-0.16 \pm 0.18$ & & \\
$\mathrm{NO}_{2}{ }^{-}+\mathrm{NO}_{3}{ }^{-}$ & $0.00 \pm 0.06$ & $-0.07 \pm 0.05$ & $0.05 \pm 0.10$ \\
$\mathrm{DON}$ & $-0.74 \pm 0.65$ & $0.01 \pm 0.47$ & $-1.00 \pm 0.78$ \\
DOC & $-11 \pm 12$ & & \\
Silicate & $-6.0 \pm 3.7$ & $-9.5 \pm 7.4$ & $-3.2 \pm 2.8$ \\
Phosphate & $-0.017 \pm 0.020$ & $-0.047 \pm 0.021$ & $0.006 \pm 0.022$ \\
\hline
\end{tabular}




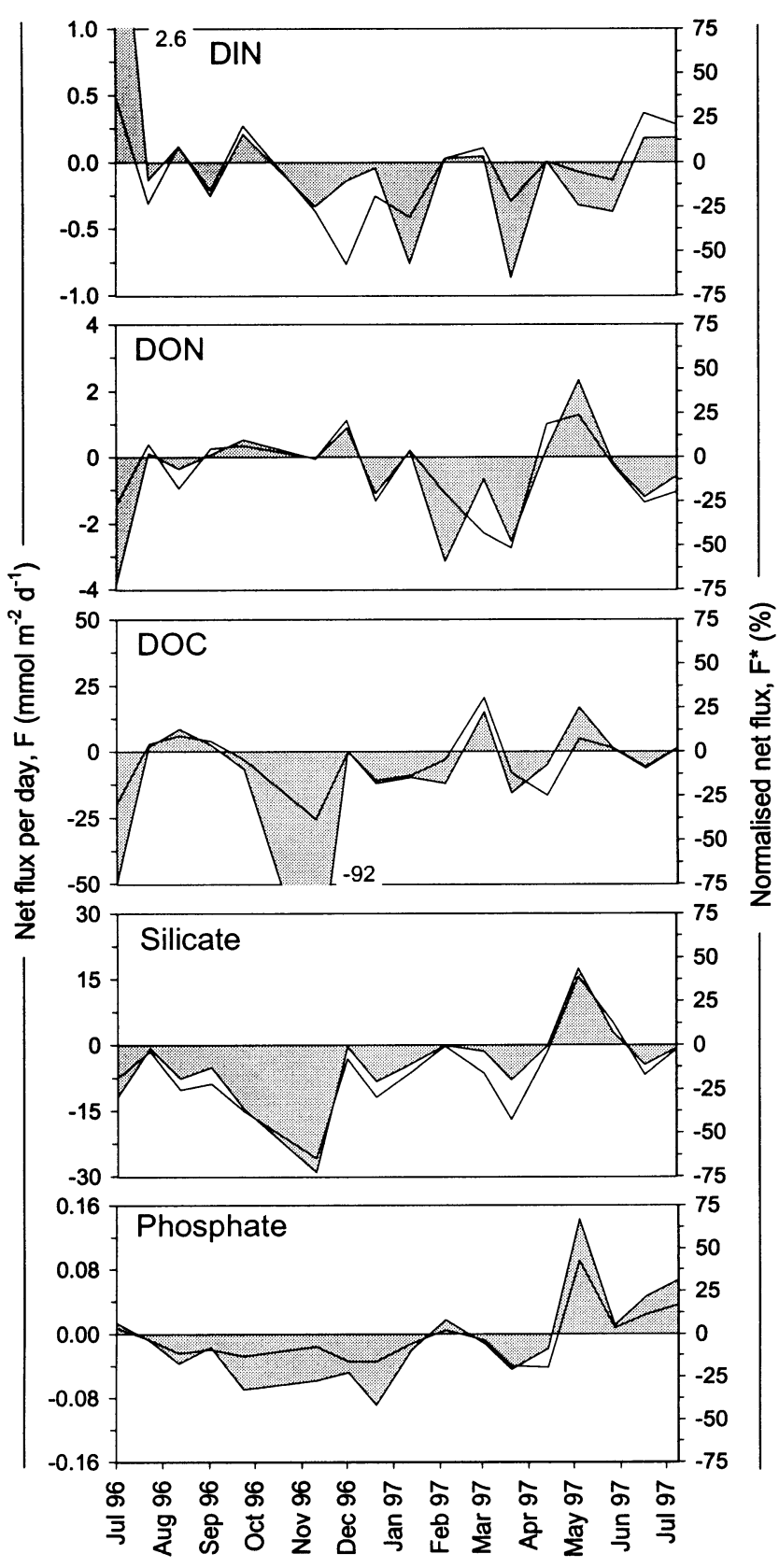

Fig. 4. Daily net fluxes, $F$ (grey) and normalised net fluxes, $F^{*}$ (line) of nutrients, DOC and DON in Furo do Meio during 1 yr. Positive values denote net inflow, negative values net outflow

\section{DISCUSSION}

\section{Evaluation of the 'Eulerian' approach}

The quality of material net-flux estimates was assessed by the analysis of water-balance asymmetries. The water flux in the tidal creek was generally balanced, i.e. the normalised net fluxes $\left(F^{*}\right)$ were generally close to zero (Fig. 6). However, a significantly
Table 2. Numbers of significantly $\left(\left|F^{*}\right|>5 \%\right)$ non-balanced flux estimates in Furo do Meio

\begin{tabular}{|c|c|c|c|c|c|c|}
\hline \multirow[t]{2}{*}{ Nutrients } & \multicolumn{2}{|c|}{$\begin{array}{c}\text { Year } \\
(\mathrm{n}=17)\end{array}$} & \multicolumn{2}{|c|}{$\begin{array}{l}\text { Dry season } \\
\quad(\mathrm{n}=7)\end{array}$} & \multicolumn{2}{|c|}{$\begin{array}{l}\text { Rainy season } \\
\qquad(\mathrm{n}=10)\end{array}$} \\
\hline & Export & Import & Export & Import & Export & Import \\
\hline DIN & 9 & 6 & 5 & 2 & 4 & 4 \\
\hline $\mathrm{NH}_{4}^{+}$ & 9 & 7 & 4 & 3 & 5 & 4 \\
\hline $\mathrm{NO}_{2}{ }^{-}+\mathrm{NO}_{3}{ }^{-}$ & 7 & 7 & 6 & 0 & 1 & 7 \\
\hline DON & 8 & 5 & 2 & 3 & 6 & 2 \\
\hline DOC & 7 & 4 & 2 & 2 & 5 & 2 \\
\hline Silicate & 11 & 2 & 6 & 0 & 5 & 2 \\
\hline Phosphate & 9 & 3 & 6 & 0 & 3 & 3 \\
\hline
\end{tabular}

non-balanced water flux was determined during the sampling campaign with the most rainfall $(22 / 23$ March 1997). A net outflow of $36 \mathrm{~mm} \mathrm{~d}^{-1}$ and a precipitation of $34 \mathrm{~mm} \mathrm{~d}^{-1}$, mainly during flood tide, was recorded. The method was therefore sensitive enough to detect this water-flux asymmetry caused by a rain-

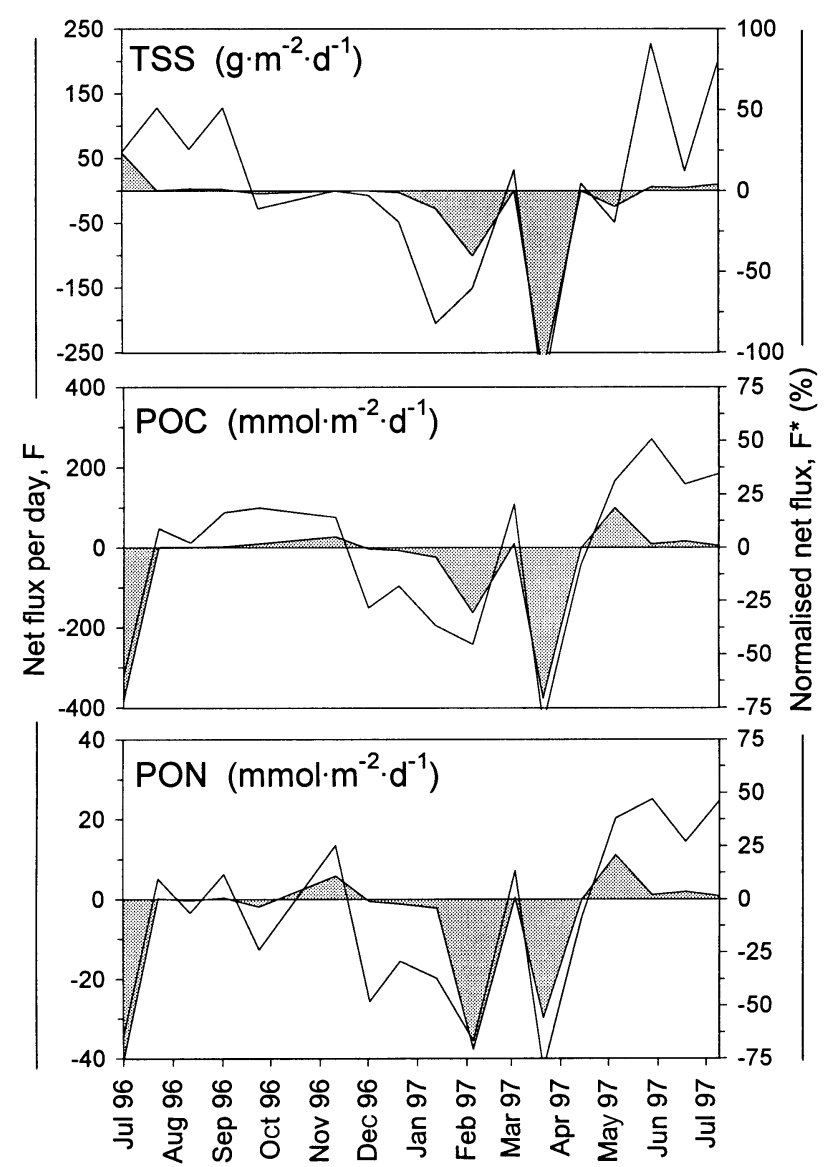

Fig. 5. Daily net fluxes, $F$ (grey) and normalised net fluxes, $F^{*}$ (line) of total suspended solids (TSS) and particulate organic matter (POC, PON) in Furo do Meio during 1 yr. Positive values denote net inflow, negative values net outflow 


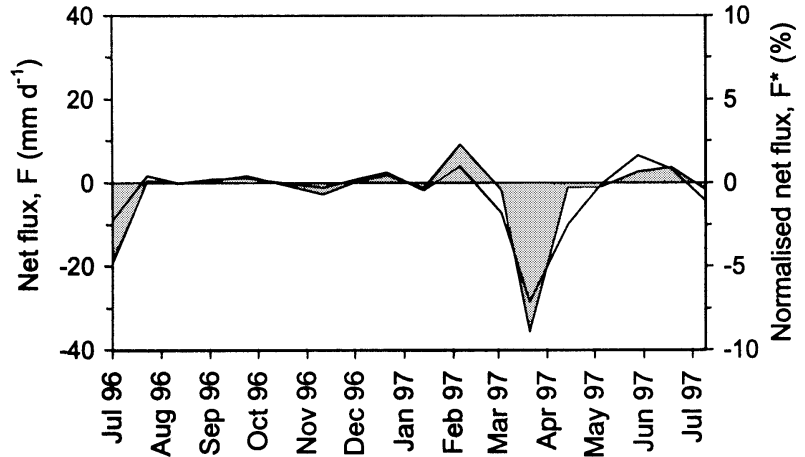

Fig. 6. Daily net fluxes, $F$ (grey) and normalised net fluxes, $F^{*}$ (line) of water in Furo do Meio during 1 yr. Positive values denote net inflow, negative values net outflow

water pulse during the flood (Table 2). This strong rainfall only contributed $7 \%\left(F^{*}\right)$ to the total water input to the catchment area (Fig. 6). All other deviations from the balanced state throughout the year of sampling were very low, and $F^{*}$ never exceeded $2 \%$. Evapotranspiration within the catchment area of Furo do Meio and smaller rainfall events had no considerable effect on the water balance. Therefore, it can be assumed that the determination of net water fluxes was sensitive. Deviations of $F^{*}$ caused by random methodological errors ranged within $\pm 2 \%$. Taking into account the inaccuracy of concentration measurements, a sensitivity of about $\pm 5 \%$ for net material fluxes $\left(F^{*}\right)$ was estimated. $\left|F^{*}\right|$ exceeding $5 \%$ was hence considered as indicative of significant deviations from the balanced state.

\section{Diel dynamics of mangrove estuary fluxes}

Nutrient dynamics in the creek are significantly influenced by porewater input from the upper forest sediment layer (Dittmar 1999, Lara \& Dittmar 1999). The nutrient-rich water at low tide is not immediately exported from the mangroves, but transported back at the beginning of flood tide (Fig. 3). In the course of the flood tide, it is mixed with nutrient-poor estuarine water and spread out in the mangrove at high tide. During the ebb tide, a comparatively well-mixed water-body leaves the mangrove. Only when most water has already flowed out and the water-body almost stagnates does the influence of porewater lead to elevated nutrient concentrations. This water, enriched with nutrients and OM, is not directly exported. It first returns to the forest and there is mixed with estuarine water.

The uptake by phytoplankton during the day (Dittmar 1999, Lara \& Dittmar 1999), leads to strongly re- duced DIN fluxes in the daytime, and therefore to a pronounced asymmetry of material fluxes between day and night. The coupling between ebb and the preceding flood tide shows that during tidal inundation biogeochemical processes in the mangrove forest itself do not influence considerably diel flux dynamics.

Determining net fluxes (in order to determine whether or not mangroves export nutrients or OM) by considering only fluxes throughout the day leads to questionable or erratic assumptions. For example, the addition of the flux increments of a whole tidal cycle throughout daytime on only 25/26 September 1996 would lead to highly negative values of DIN exchange, indicating a strong outwelling of DIN. The calculation of net fluxes throughout a whole lunar day however, revealed an almost balanced DIN net exchange. Some studies on nutrient and OM fluxes in mangroves only considered fluxes throughout the daytime, in disregard of the considerable effects of phototrophic organisms (Boto \& Bunt 1981, Boto \& Wellington 1988). This might be a reason for some inconsistencies in this field, apart from the potentially large errors introduced through inaccuracies in flow and concentration measurements.

\section{Net fluxes between mangroves and estuary}

The qualitative whole-estuary approach for dissolved inorganic nutrients coincides in an encouraging way with the flux determination at Furo do Meio: a continuous export of DIN and silicate during the whole year from the mangrove, and export of phosphate mainly in the dry season. This finding indicates, firstly, that export from the mangrove forest led to the increased concentrations of DIN, silicate and phosphate in the estuary, and, secondly, that the export characteristics of Furo do Meio were on average representative of the whole mangrove area in the Caeté Estuary. DIN was exported almost completely in form of ammonium. This is reasonable, since the flux of ammonium-rich porewater from the reducing mangrove sediments is considered to be the principal source of DIN in the tidal creek (Dittmar 1999, Lara \& Dittmar 1999).

In the case of DOM, the 2 approaches are not consistent. At Furo do Meio, a net export of DON and DOC was determined which accounted, on a carbon basis, for $\sim 10 \%$ of the annual litter fall (Mehlig 1999). The whole-estuary approach, however, did not reveal clear evidence for DOM outwelling. Dittmar (1999) found molecular evidence for strong DOM outwelling from the mangroves and a geochemical barrier zone for terrestrial DOM in the Caeté Estuary. The decrease of DOC relative to conservative mixing in the upper part 
of the estuary at salinities below 2 in March 1997 (Fig. 2b) supports the existence of such barrier zone. Lapin et al. (1990) observed that most terrigenous DOM was deposited or altered within a salinity range of 1 to 24 in a Japanese estuary, similar to the conditions in the Caeté Estuary. Probably because of the antagonistic effects of DOM outwelling and transformation within the estuarine water column, the mixing diagrams did not reveal export of DOM from the mangrove system. Some of the DON dynamics in the estuary may also be related with DON release from particles, suggested by the coupling of the net fluxes of DON and PON in Furo do Meio.

A striking feature of the material exchange is that the total amount of water flowing between mangroves and estuary, which oscillates by an order of magnitude between spring and neap tides, has no considerable influence on direction and amount of material balances. Furthermore, changes in the concentration level in the creek, i.e. the daily average concentrations, had no direct effect on the material balances - daily average concentrations showed different annual trends than did fluxes (Dittmar 1999). This indicates that net fluxes are more likely to be controlled by modifications in the symmetry of the concentration curves throughout a tidal cycle than by other processes that change average concentrations. Therefore, the annual oscillations of material fluxes could be related neither to different inputs of nutrient-rich mangrove porewater to the creek, nor to seasonal changes in litter fall. Cohen et al. (2001) found evidence for the immobilisation of dissolved phosphate during mangrove inundation, probably due to the formation of Ca-species with lowsolubility constants. This process might lead to asymmetries in the tidal concentration oscillations, and therefore effect stronger daily net fluxes than average concentrations. Seasonal alterations in the physicochemical properties of the mangrove sediment (Schwendenmann 1998) could thus cause the differences in phosphate export between dry and rainy seasons. Phytoplanktonic activity had a considerable effect on nitrogen and OM concentrations in the creek and, depending on the time of low tide, also on the symmetry of their tidal oscillations (Dittmar 1999). This asymmetry may change the nitrogen and carbon balances.

Compared to other mangrove areas in the world, the net export estimates of dissolved nutrients and DOM from the mangrove area in Bragança were generally higher. Only the net exchange of DOC determined in Rookery Bay, Florida (Twilley 1985) agreed with the net export estimates for Bragança, in spite of different characteristics of the relative mangroves. The tidal range was much lower in Rookery Bay $(0.55 \mathrm{~m})$, but was similar to Bragança in that the mangrove forest was flooded infrequently. Unfortunately, no data on inorganic nutrient exchange are available from the Rookery Bay area. Unlike Bragança and Rookery Bay, a slight import of DOC to the mangrove was determined at Coral Creek, Hinchinbrook, Australia (Boto \& Wellington 1988, Ayukai et al. 1998). At Conn Creek, adjacent to Coral Creek, Ayukai et al. (1998) recently estimated a DOC net export of $4.8 \mathrm{mmol} \mathrm{m}^{-2} \mathrm{~d}^{-1}$. Variations in the amount of freshwater input into these mangrove creeks seemed to be an important factor affecting the direction and magnitude of material fluxes (Ayukai et al. 1998). Maximum silicate exports estimated for Klong Ngao, Thailand (Wattayakorn et al. 1990) and Hinchinbrook Island (Ayukai et al. 1998) agree with the average values determined for Bragança. At Klong Ngoa, maximum net exports of phosphate and total dissolved nitrogen were similar to the average values at Furo do Meio. Simpson et al. (1997) found a large variability in nutrient fluxes between a mangrove swamp and adjacent coastal waters in Sungai Merbok Estuary in Malaysia. They concluded an almost balanced net exchange for nitrate.

Because of the scarcity of net flux estimates in mangrove forests in general, one can merely speculate about the reasons for the comparatively strong outwelling from the North-Brazilian mangrove system. The litter-collecting activity of land crabs in Bragança, and the consequently high proportion of litter mineralisation within the sediment, may be a key factor accounting for the export of dissolved nutrients and OM.

\section{CONCLUSIONS}

From a methodological point of view, the detailed analyses of fluxes showed that a high temporal resolution in the order of minutes, and the consideration of day and night fluxes is imperative for reliable detection of outwelling and its extent. Long-term studies are the only way to characterise successfully export from mangroves, because of seasonality of outwelling. The application of a qualitative mixing model proved an adequate tool for examining the results of quantitative flux estimates.

Both methods of estimating material fluxes between mangroves and estuary on the scale of the catchment area of a mangrove tidal creek $\left(2.2 \mathrm{~km}^{2}\right)$ and on a whole-estuary scale (190 $\mathrm{km}^{2}$ of mangroves), revealed a net export of dissolved nutrients from the mangrove system that exceeded that of other mangroves in the world. This export must be compensated by additional sources to the mangrove forest to sustain the welldeveloped forests of the Caeté Estuary. Nitrogen outwelling may be balanced by $\mathrm{N}_{2}$-fixation, which was 
identified as the primary nitrogen source in many mangrove ecosystems (e.g. Potts 1984, Boto \& Robertson 1990, Morell \& Corredor 1993). A positive sedimentation balance in the long-term and mineralisation in the mangrove sediment presumably compensate the export of dissolved silicate and phosphate.

The amount of nutrient outwelling from the mangrove was higher than the input to the ocean by freshwater sources, i.e. the Caeté River. The fact that only about $6 \%$ of the whole fluvial catchment area is covered by mangroves illustrates the extent of this outwelling. Thus mangroves, rather than rivers, support marine production. These findings are in good agreement with a recent organic tracer study (Dittmar 1999), which found evidence for outwelling of mangrove-derived OM that exceeded the export of other terrestrial OM. Since similar geomorphologic features caused the development of analogous biological units along the entire coastline southeast of the Amazon estuary, the results of this study were extrapolated to the mangroves of the Brazilian states Pará and Maranhão $\left(10^{\circ} \mathrm{S}\right.$, $50^{\circ} \mathrm{W}$ to $3^{\circ} \mathrm{S}, 42^{\circ} \mathrm{W}$ ). The annual export from this man-

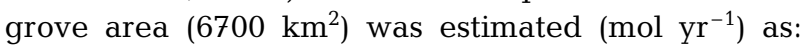
DOC $\approx 30 \times 10^{9}$, DON $\approx 2 \times 10^{9}$, ammonium $\approx 0.4 \times 10^{9}$, silicate $\approx 15 \times 10^{9}$ and phosphate $\approx 0.04 \times 10^{9}$. Compared with the Amazon River discharge (Richey \& Victoria 1993) these fluxes are low $(1-3 \%$ of the Amazon fluxes). The marine biogeochemical cycles northwest of the Amazon Estuary are strongly influenced by the high riverine input, which is transported there by the North Brazil Current. Contrary to this river-dominated region, the coastal nutrient cycles southeast of the Amazon seem to be mangrove-dominated.

Acknowledgements. We thank M. Birkicht and O. Gundermann for their excellent technical assistance. We are also grateful to D. Schories for providing TSS data. We thank G. Kattner, T. Spence and 3 anonymous referees for revising this manuscript. This study was carried out as part of the Brazilian-German co-operation project MADAM, and was financed by the Brazilian National Research Council (CNPq) and the German Ministry for Education and Research (BMBF) under project code no. 03F0154A. This is MADAM Contribution No. 24.

\section{LITERATURE CITED}

Alongi DM (1990) Abundances of benthic microfauna in relation to outwelling of mangrove detritus in a tropical coastal region. Mar Ecol Prog Ser 63:53-63

Alongi DM (1996) The dynamics of benthic nutrient pools and fluxes in tropical mangrove forests. J Mar Res 54:123-148

Alongi DM, Boto KG, Tirendi F (1989) Effect of exported mangrove litter on bacterial productivity and dissolved organic carbon fluxes in adjacent tropical nearshore sediments. Mar Ecol Prog Ser 56:133-144

Alongi DM, Ayukai T, Brunskill GJ, Clough BF, Wolanski E
(1998) Sources, sinks, and export of organic carbon through a tropical, semi-enclosed delta (Hinchinbrook Channel, Australia). Mangroves Salt Marshes 2:237-242

Ayukai T, Miller D, Wolanksi E, Spagnol S (1998) Fluxes of nutrients and dissolved and particulate organic matter in 2 mangrove creeks in north-eastern Australia. Mangroves Salt Marshes 2:223-230

Boto KG, Bunt JS (1981) Tidal export of particulate organic matter from a northern Australian mangrove system. Estuar Coast Shelf Sci 13:247-255

Boto KG, Robertson AI (1990) The relationship between nitrogen fixation and tidal exports of nitrogen in a tropical mangrove system. Estuar Coast Shelf Sci 31:541-554

Boto KG, Wellington JT (1988) Seasonal variations in concentrations and fluxes of dissolved organic and inorganic materials in a tropical, tidally-dominated, mangrove waterway. Mar Ecol Prog Ser 50:151-160

Clough B (1998) Mangrove forest productivity and biomass accumulation in Hinchinbrook Channel, Australia. Mangroves Salt Marshes 2:191-198

Cohen M, Lara RJ, Szlafsztein CF, Dittmar T (2001) Mangrove inundation and nutrient dynamics under a GIS perspective. Wetlands Ecol Manage (in press)

Dittmar T (1999) Outwelling of organic matter and nutrients from a mangrove in north Brazil: evidence from organic tracers and flux measurements. Center for Tropical Marine Ecology, Bremen (ZMT Contrib. No. 5)

Gils H (1958) Über die Anwendbarkeit abgekürzter Abflußmeßverfahren. Dtsch Gewässerkd Mitt 1:5-9

Hansen HP, Grasshoff K (1983) Automated chemical analysis. In: Grasshoff K, Erhardt M, Kremling K (eds) Methods of seawater analysis. Verlag Chemie, Weinheim, p 347-377

INMET (1992) Normas climatológicas. Instituto Nacional de Meteorologia, Brasilia DF

Kjerfve B, Stevenson LH, Proehl JA (1981) Estimation of material fluxes in an estuarine cross section: a critical analysis of spatial measurement density and errors. Limnol Oceanogr 26:325-335

Koroleff F (1977) Simultaneous persulphate oxidation of phosphorus and nitrogen compounds in water. In: Grasshoff $\mathrm{K}$, Kremling K, Erhardt M, Osterroth C (eds) Methods of seawater analysis. Report Baltic Intercal Workshop 7-9 Mar 1977, Annex. Compiler, Universität Kiel, p 29-31

Koroleff F (1983) Total and organic nitrogen. In: Grasshoff K, Erhardt M, Kremling K (eds) Methods of seawater analysis. Verlag Chemie, Weinheim, p 162-173

Kreps H (1975) Praktische Arbeit in der Hydrographie. Hydrographisches Zentralbüro im Bundesministerium für Land- und Forstwirtschaft, Wien

Lapin IA, Anikiyev VV, Vinnikov YY, Tambiyeva NS, Shumilin YN (1990) Biogeochemical aspects of the behavior of dissolved organic matter in the Razdolnaya river estuary (Amor Gulf, Sea of Japan). Oceanol Acad Sci USSR 30:170-174

Lara RJ, Dittmar T (1999) Nutrient dynamics in a mangrove creek (North Brazil) during the dry season. Mangroves Salt Marshes 3:185-195

MacGill JT (1958) Map of coastal landforms of the world. Geogr Rev 48:402-405

Mehlig U (1999) Aspectos da produção primária nos manguezaiz de Bragança. $5^{\circ}$ workshop do programma MADAM, Belém, Brazil, 10-12 Nov 1999. Conference Abstr., Center for Tropical Marine Ecology, Bremen, p 66-67

Morell JM, Corredor JE (1993) Sediment nitrogen trapping in a mangrove lagoon. Estuar Coast Shelf Sci 37:203-212

Odum EP, Heald EJ (1975) The detritus bases food web of an estuarine mangrove community. In: Cronin LE (ed) Estuarine research. Academic Press, New York, p 265-286 
Potts M (1984) Nitrogen fixation in mangrove forests. Hydrobiology of the mangal. The ecosystem of the mangrove forests. In: Por FD, Dor I (eds) Development in hydrobiology. Dr W Junk, The Hague, p 155-162

Richey JE, Victoria RL (1993) C, N, and P export in the Amazon River. In: Wollast R, Mackenzie FT, Chou L (eds) Biogeochemical cycles and global change. Springer-Verlag, Berlin, p 123-139

Rivera Monroy VH, Day JW, Twilley RR, Vera Herrera F, Coronado Molina C (1995) Flux of nitrogen and sediment in a fringe mangrove forest in Terminos Lagoon, Mexico. Estuar Coast Shelf Sci 40:139-160

Robertson AI, Alongi DM, Boto KG (1992) Food chains and carbon fluxes. In: Robertson AI, Alongi DM (eds) Tropical mangrove ecosystems. Coastal and Estuarine Series No. 41. American Geophysical Union, Washington, p 293-326

Schwendenmann L (1998) Tidal and seasonal variations of

Editorial responsibility: Otto Kinne (Editor),

Oldendorf/Luhe, Germany soil and water properties in a Brazilian mangrove ecosystem. MSc thesis, Universität Karlsruhe

Simpson JH, Gong WK, Ong JE (1997) The determination of the net fluxes from a mangrove estuary system. Estuaries 20:103-109

Skoog A, Thomas D, Lara R, Richter KU (1997) Methodological investigations on DOC determinations by the HTCO method. Mar Chem 56:39-44

Statham PJ, Williams PJL (1983) Determination of total $\mathrm{CO}_{2}$. In: Grasshoff K, Erhardt M, Kremling K (ed) Methods of seawater analysis. Verlag Chemie, Weinheim, p 378-383

Twilley RR (1985) The exchange of organic carbon in basin mangrove forest in a southwestern Florida estuary. Estuar Coast Shelf Sci 20:543-557

Wattayakorn G, Wolanski E, Kjerfve B (1990) Mixing, trapping and outwelling in the Klong Ngao mangrove swamp, Thailand. Estuar Coast Shelf Sci 31:667-688

Submitted: April 3, 2000; Accepted: August 22, 2000

Proofs received from author(s): March 2, 2001 